\title{
Przestrzeń pożydowska
}

\author{
Konrad Matyjaszek
}

\begin{abstract}
Abstrakt: Artykuł zawiera krytyczną analizę współczesnych strategii zmian oraz modyfikacji w pożydowskich dzielnicach w Polsce. Większość substancji miejskiej w tych rejonach składa się z nieruchomości wcześniej należących do polskich Żydów, a później przywłaszczonych przez Polaków nieżydowskiego pochodzenia podczas Holokaustu oraz po roku 1945. Tego typu nieruchomości nazywa się obecnie „mieniem pożydowskim”.

Autor analizuje dwa równolegle działające procesy adaptacji tej przestrzeni miejskiej. Pierwszy z nich zasadza się na koncepcji „przestrzeni żydowskiej”, przedstawionej w 1999 roku przez Dianę Pinto. „Przestrzeń żydowska”, pierwotnie zdefiniowana jako kulturalne i materialne miejsce spotkań europejskich Żydów oraz ludności pochodzenia nieżydowskiego, w polskim kontekście nie wymaga realnej obecności Żydów. Co za tym idzie, praktyki społeczne wynikające z tej interpretacji idei „przestrzeni żydowskiej” daleko odbiegają od pierwotnego zamysłu Pinto.

Drugi proces opisany w artykule dotyczy fizycznej realizacji tak zdefiniowanego „miejsca spotkań”. Analizowany jest on na przykładzie Dotleniacza - instalacji miejskiej z 2007 roku autorstwa Joanny Rajkowskiej. Praca Rajkowskiej była jedną z pierwszych prób stworzenia fizycznego miejsca spotkań w Polsce. Pomimo altruistycznych założeń, które legły u podstaw projektu, nie mógł on w pełni wyrwać się z okowów dyskursu na temat „dialogu” ekskluzywistycznego. Tak więc kulturowa interpretacja Dotleniacza została zawężona do znaczeń, których owocem będzie raczej wykluczenie, a nie możliwość uczestnictwa.

Wyrażenia kluczowe: Warszawa, stosunki polsko-żydowskie, mienie żydowskie, miejsce i przestrzeń, sztuka publiczna
\end{abstract}

\footnotetext{
„Pamiętam, kiedy po wojnie usłyszałam to słowo, powiedziane głośno pierwszy raz. Nie było to zresztą słowo «żyd», tylko «żydowskie». A ściślej - «pożydowskie».

- To są pożydowskie rzeczy - zachęcał moją matkę miły, starszy pan, który w pomocy społecznej rozdawał dzieciom mleko w proszku i ubrania.

- Sama pani widzi, jaki gatunek".

Hanna Krall, Sublokatorka (Krall, 1985, s. 113)
}

Termin „mienie pożydowskie” jest dla polskich miast pojęciem konceptualizującym stan początkowy. Uosabia on rodzaj amorficznej substancji, z której po roku 1945 wyłoniły się mapy i plany, struktury urbanistyczne znane nam dzisiaj. Na równi z mitologią miejską wywodzącą początki polskich miast od królewskich aktów lokacyjnych określenie współczesnego stanu rzeczy zawarte w pojęciu „mienie pożydowskie” stanowi rodzaj założycielskiego mitu-opowieści przestrzeni, w których się urodziliśmy i które zamieszkujemy. Źródłem opowieści i źródłem przestrzeni pozostaje przywłaszczanie ruchomej i nieruchomej własności ofiar Zagłady oraz własności ocalałych, praktykowane przez Polaków pomiędzy początkiem drugiej wojny światowej a latami pięćdziesiątymi XX wieku. W pierwszych miesiącach powojennych przywłaszczanie to, wcześniej odbywające się spontanicznie, znalazło swoją prawną regulację w postaci dekretu o majątkach 
opuszczonych i poniemieckich ${ }^{1}$. Stało się w ten sposób podstawą nowego porządku przestrzennego miast oraz nowego porządku społecznego ich mieszkańców, kształtując materialne zaplecze ich (naszych) wyborów i awansów. Po części z tego powodu nie mamy dziś - jako społeczeństwo - większego problemu z użyciem terminu „mienie pożydowskie" w codziennej mowie i powszednim życiu². Jedyny rodzaj wątpliwości czy niepokoju, który towarzyszy używaniu tej codziennej struktury językowej i stanowi ostatecznie o jej prowizorycznym charakterze, powodowany jest chybotliwą podstawą prawną tak uzyskanego majątku. Jak to ujęli Jan Tomasz Gross i Irena Grudzińska-Gross: „zamordowanie albo wypędzenie człowieka nie daje nikomu tytułu własności do niczego, w tym również do pracy skumulowanej przez pokolenia w nagromadzonych przedmiotach. «Pożydowska» może być tylko la façon de parler, a nie żadna własność, o czym świetnie wiedzą mieszkańcy polskich miasteczek, niepokojąc się, kiedy tylko w okolicy pojawi się ktoś obcy, czy to aby przypadkiem nie jakiś Żyd lub na pewnych terenach Niemiec, który przyjechał «po swoje»" (Gross \& Grudzińska-Gross, 2011, s. 146)³.

Niniejszy tekst stanowi analizę powszechnej strategii postępowania z kategorią przestrzeni polskich miast, zwaną „mieniem pożydowskim”. Strategia ta składa się z dwóch równoległych wobec siebie czynności o charakterze rekompozycji i adaptacji, których obiektami są język służący opisowi przestrzeni miejskiej oraz sama przestrzeń. W ramach pierwszego zabiegu postulat „przestrzeni żydowskiej”, sformułowany przez Dianę Pinto, poddawany jest demontażowi. Wybrane wątki służą do konstruowania nowej narracji o polsko-żydowskim dialogu, zastępującej narracje wcześniejsze, niosące w sobie ślady

1 Mowa o Dekrecie z dnia 8 marca 1946 r. o majątkach opuszczonych i poniemieckich („Dekret z dnia 8 marca 1946”, 1946). Według podanej w dokumencie definicji mienie opuszczone to „wszelki majątek (ruchomy i nieruchomy) osób, które w związku z wojną rozpoczętą 1 września 1939 r. utraciły jego posiadanie, a następnie go nie odzyskały”. Jest nim też „majątek będący w posiadaniu osób trzecich na podstawie umowy zawartej z właścicielem [...], jeśli umowa ta miała na celu uchronienie tego majątku od utraty w związku z wojną lub okupacją". Na mocy dekretu majątek taki stawał się własnością skarbu państwa z teoretyczną opcją zwrotu własności w trybie postępowania sądowego. Dekret ten nie był pierwszym aktem regulującym status prawny „mienia pożydowskiego” - jeszcze przed zakończeniem działań wojennych wydano Dekret z dnia 2 marca 1945 r. o majątkach opuszczonych i porzuconych („Dekret z dnia 2 marca 1945 r.", 1945)

2 Termin należy do kategorii pojęć, które Joanna Tokarska-Bakir nazwała skamielinami językowymi, „aktywnymi miejscami w języku", niosącymi w sobie treści wykraczające daleko poza nominalne brzmienie tego, co wypowiedziane (Tokarska-Bakir, 2008, ss. 39-47). Termin ten jest też formułą o precyzyjnej konstrukcji i zastosowaniu. Jan Tomasz Gross i Irena Grudzińska-Gross zwrócili uwagę na bardzo ograniczone użycie przedrostka „po-” w związkach frazeologicznych odnoszących się do własności „opuszczonej”. Jak pisali, „ten nowotwór językowy pojawia się w języku polskim tylko w trzech wariantach: «pożydowskie», «poniemieckie» i «podworskie». [...] Za sprawą okoliczności historycznych w XX wieku mieliśmy do czynienia w Polsce z trzema procesami przywłaszczenia na masową skalę cudzej własności - po wypędzeniu ludności niemieckiej, po wymordowaniu Żydów i po zlikwidowaniu ziemiaństwa jako tzw. wroga klasowego" (Gross \& Grudzińska-Gross, 2011, s. 146).

Znacząca jest pewna bezradność języków obcych w tłumaczeniu tej kluczowej dla opowieści o naszych miastach formuły. Michael Meng przekłada „mienie pożydowskie” uładzoną angielską frazą formerly Jewish property, jednocześnie zaznaczając, że tłumaczenie to w „niewielkim stopniu oddaje dyskursywną moc polskiego oryginału” (Meng, 2011, s. 50). Część autorów anglojęzycznych publikacji używa fonetycznie bliskiego sformułowania post-Jewish (Adamczyk-Garbowska \& Polonsky, 2001, s. xxvi). Pełnia dyskursywnej mocy zdaje się emanować z tłumaczenia ex-Jewish, którego użyli Stanisław Barańczak i Clare Cavanagh w tłumaczeniu wiersza Jerzego Ficowskiego o tytule Pożydowskie (Barańczak \& Cavanagh, 1991, s. 91). Łaciński przedrostek ex-, znaczący tyle, co „na zewnątrz”, „poza”, zarówno w języku polskim, jak i angielskim znajduje zastosowanie w pokrewnych „pożydowskiemu” terminach oznaczających wyłączenie (exclusion), wykluczenie (expulsion), ekspropriację (expropriation) i eksterminację (extermination). Tłumaczenia ex-Jewish użył ostatnio również architekt Jakub Szczęsny, objaśniając nim lokalizację swojej instalacji Dom Kereta, znajdującej się obok „pożydowskiej kamienicy” na ulicy Żelaznej w Warszawie - sądzić należy, że bez pełnej wiedzy o celności tego tłumaczenia (Szczęsny, b.d.).

3 W miarę kompletny katalog przejawów tego niepokoju stanowi ostatni rozdział książki Wojciecha Wilczyka Niewinne oko nie istnieje (Wilczyk, 2009, ss. 665-681). Zawiera zapis rozmów, w których autor uczestniczył z konieczności podczas wykonywania projektu fotograficznego dokumentującego budynki synagog w polskich miastach. 
historii powojennego przejęcia własności. Drugi - równoległy - zabieg jest działaniem na fizycznej przestrzeni miejskiej. Stanowi on architektoniczną adaptację „mienia pożydowskiego" zgodną z tradycyjnym miejscem, jakie wyznacza się Żydom w polskiej przestrzeni publicznej. Temu podwójnemu, lecz w swojej technicznej naturze jednorodnemu, zjawisku chcę się przyjrzeć, analizując kolejno losy postulatu „przestrzeni żydowskiej” oraz strukturę warszawskiej interwencji miejskiej Dotleniacz autorstwa Joanny Rajkowskiej, będącej jedną z pierwszych prób fizycznej konfiguracji przestrzeni spotkania.

\section{dzielnica żydowska}

Szansa usunięcia wspomnianej wyżej niestabilności znaczeniowej (a z nią i prawnej) „pożydowskiego mienia” pojawiła się w ostatnich latach XX wieku, z miejsca wyznaczając nowe ramy polskiego dyskursu planistycznego. Był to wyjątkowy czas. Widziana oczami zewnętrznego obserwatora topografia polskich miast stawała się nagle przestrzenią dającą się mapować i oglądać, fragmentem bytu określanego mianem „Europy Środkowo-Wschodniej”. Ruch ten wysunąt „mienie pożydowskie” z komfortowego cienia, czyniąc z niego obiekt obserwacji i analiz.

Przesunięcie to przyniosło - $\mathrm{z}$ jednej strony - serię zabiegów dokonywanych przez polskich planistów, dążących do uwiarygodnienia powojennego kształtu co istotniejszych miast za pomocą strategii określanych zbiorczym mianem rewitalizacji ${ }^{4}, \mathrm{z}$ drugiej strony zaś spowodowało uruchomienie wysiłków badaczy próbujących z grubsza zrozumieć i nazwać wszystko, co zaczęło się wówczas dziać wokół architektonicznego „mienia pożydowskiego".

Działo się wiele. Był to kluczowy moment w dziejach współczesnej urbanistyki polskiej, kiedy pozostałości nazistowskich i dawniejszych gett przestały być wstydliwie zasłanianymi dzielnicami ruder, przemieniając się w oczach polskiej większości w „dawne dzielnice żydowskie", dumę miast i źródło ich dochodu. Proces ten - trwający w zmiennym natężeniu do dzisiaj i skutkujący transformacją całych pierzei, kwartałów i dzielnic - spowodował jednocześnie głód języka opisującego to zjawisko, nagły deficyt nazw mogących skodyfikować nasz niespodziewany awans na strażników „żydowskiego dziedzictwa”. Nasz, czyli polskiej większości ukonstytuowanej na przejętym w trakcie okołowojennych migracji mieniu i umocowanej w dominującej narracji historycznej, w której uczestnictwo bywa warunkiem zabrania głosu. Częścią tej narracji jest opowieść o nas samych jako „strażnikach żydowskiego dziedzictwa”, niestabilna i problematyczna, gdyż niosąca w sobie pytanie o naturę dziedziczenia, o osobę dziedziczącą oraz o sposób, jak dziedzictwo zostało nabyte ${ }^{5}$. Aby uregulować znaczeniowy deficyt wynikający z opi-

4 Jednym z pierwszych projektów rewitalizacyjnych była opracowana w 1994 roku przez międzynarodowy zespół planistów pod redakcją Camerona Davida Rodericka strategia dla krakowskiego Kazimierza: Kazimierz - plan dziatań. Projekt opracowany przez miasta Kraków, Edynburg i Berlin w ramach programu Unii Europejskiej ECOS, 1993-1994.

5 Proces montażu opowieści o Polaku - strażniku dziedzictwa żydowskiego, figury funkcjonującej w polskiej kulturze jako tożsamej z figurą świadka Zagłady, omawiają Elżbieta Janicka i Tomasz Żukowski w artykule zamieszczonym w pierwszym numerze niniejszego pisma (Janicka \& Żukowski, 2012, ss. 14-17). Autorzy piszą: „Wprowadzenie kategorii «strażnika pamięci» i «świadka» pozwala zasugerować wspólnotę polsko-żydowską [...]. Tymczasem 
sanej niestabilności, nazwy zastępcze czerpaliśmy i czerpiemy ze wszelkich dostępnych źródeł, a ich ciągły niedobór powoduje tolerancję na struktury językowe będące - w odniesieniu do wypełniającej je społecznej praktyki - skrajnie nieprzekonującymi. Szeroko stosuje się terminologię w rodzaju „dzielnicy dialogu czterech wyznań” lub też „miasta trzech kultur"6, co musi nam wystarczyć w sytuacji, w której alternatywnym określeniem miejskich dzielnic przeznaczonych dla Żydów przed Zagładą pozostaje dobrze znane, jakkolwiek w sytuacji istnienia zewnętrznej perspektywy, coraz bardziej nieużyteczne - „pożydowskie”.

\section{Jewish Space: demontaż, adaptacja}

Opowieść o „dzielnicach dialogu” jest polskim produktem, jednak słowa, z których ją ułożyliśmy, już niekoniecznie. Pochodzą z debaty wywołanej nagłą atencją, jaką w naszej części Europy obdarzono relikty żydowskiego mienia, a dotyczącej żydowskiej obecności w rozszerzającym się po 1989 roku europejskim obiegu kultury. Tekstem, który ją zapoczątkował i który wkrótce stać się miał obiektem polskich zabiegów demontażu i adaptacji, był esej Diany Pinto zatytułowany The Third Pillar? Toward a European Jewish Identity ('Trzeci filar? Ku europejskiej tożsamości żydowskiej') (Pinto, 1999). Esej ten nie dotyczył wcale problemów miejskich. Zamieszkała w Paryżu historyczka i badaczka kultury postulowała przedyskutowanie udziału europejskich Żydów w szeroko pojętej europejskiej przestrzeni publicznej. Przestrzeń tę rozumiała jako strukturę społeczną i polityczną, odnajdującą swoje miejsce w fizycznych lokalizacjach. Społeczno-topograficzne zjawisko mające ten współudział skodyfikować określiła mianem „przestrzeni żydowskiej” (Jewish Space). Określała ją jako „otwartą agorę kulturalną czy nawet polityczną, w której Żydzi mogą spotykać się z innymi j a k o Żydzi, nie tylko jako obywatele" (Pinto, 1999). W jej wizji „przestrzeń żydowska” „to miejsce, w którym pojawiać się mogą debaty, w którym przedyskutować można opinie, a konflikty rozwiązywać czy też w ogóle artykułować, gdyż «przestrzeń żydowska» nie może zaistnieć bez przestrzeni dla demokratycznego pluralizmu”. Zdaniem autorki, „,nie może ona istnieć bez Żydów, ale też nie może istnieć tylko za ich sprawą, gdyż «przestrzeń» nie jest odpowiednikiem społeczności” (Pinto, 1999).

O postulacie Pinto dyskutowano od momentu jego publikacji, wydaje się jednak, że wywołał inną dyskusję niż ta, której spodziewała się autorka. Temat „przestrzeni żydowskiej" podjęli uczestnicy debaty toczącej się wokół środkowoeuropejskiego fenomenu „kultury żydowskiej bez Żydów”, praktykowanej w przestrzeniach świeżo nazwanych

przejmowanie żydowskich rzeczy przez Polaków - by nazwać rzecz eufemistycznie - było zjawiskiem masowym Odbywało się w sytuacji, która w skali grup społecznych nie pozostawiała miejsca na bycie świadkiem. Uniemożliwia też nazwanie polskiej społeczności strażnikiem pamięci bez dodatkowych wyjaśnień. Świadek to ktoś, kto przygląda się z boku, nie uczestniczy w sytuacji i nie ma wpływu na to, co się dzieje. [...] Społeczność, która nie pozwoliła Żydom ukryć się po aryjskiej stronie i jednocześnie masowo czerpała materialne korzyści z ich wymordowania, nie może określać się mianem «świadków», ani tym bardziej: «strażników pamięci»" (Janicka \& Żukowski, 2012, ss. $15-16)$.

6 „Dzielnica Czterech Wyznań” to fragment wrocławskiego Starego Miasta, którego pełna nazwa promocyjna brzmi: „Dzielnica Wzajemnego Szacunku Czterech Wyznań”. Łódź jest promowana jako „Miasto Dialogu Czterech Kultur”, natomiast podlubelska Włodawa to „Miasto Trzech Kultur”. W liczbie kultur występuje zawsze „kultura polska” i „kultura żydowska”, pozostałe pojawiają się zamiennie, w zależności od regionu. 
„dzielnicami żydowskimi”. W ramach międzynarodowego nurtu tej debaty „przestrzeń żydowską" opisywano jako tożsamą z tym fenomenem i w takim ujęciu poddawano analizie. Niemiecki badacz Joachim Schlör pisał o niej jako o „decydującej idei”, w której szczególnie istotny jest wątek jej rozszerzenia, „oznaczający, że przestrzeń ta zamieszkiwana i użytkowana jest również przez nie-Żydów" (Schlör, 2003, s. 149). W polskim wątku dyskusji - włączonej dosyć późno w sferę języka polskiego - nadinterpretacje sięgały znacznie dalej. W pokonferencyjnej publikacji krakowskiego Międzynarodowego Centrum Kultury Magdalena Waligórska pisała: „Diana Pinto, która ukuła termin Jewish Space dla opisania rosnącego zainteresowania Europejczyków nieżydowskiego pochodzenia dziejami i dziedzictwem Żydów, użyła metafory przestrzeni dla podkreślenia tego, że to spotkanie kultur jest otwarte na wzór agory. Spotkanie Żydów i nie-Żydów, którzy interesują się kulturą żydowską i czasami ją współtworzą, nie musi odbywać się w przestrzeniach historycznie żydowskich, te jednak często stają się symbolami takiego dialogu" (Waligórska, 2008, s. 115). Pośród atmosfery „przywracania pamięci dzielnic żydowskich” dokonał się stopniowy demontaż koncepcji „przestrzeni”, z której w pierwszej kolejności usunięto warunkowy charakter jej istnienia, zależny od „demokratycznego pluralizmu”, pozwalający na debatę. Czego ta debata mogłaby dotyczyć, sugerowała sama Pinto, pisząc o potrzebie dekonstrukcji europejskich opowieści o Zagładzie budowanych wzdłuż „łatwych, lecz niezbyt użytecznych linii podziału” pomiędzy powojennymi zwycięzcami a przegranymi, sprawcami a niewinnymi świadkami (Pinto, 1999).

Końcowym narzędziem upowszechnienia wybranych komponentów eseju stała się wydana w 2002 roku książka Ruth Ellen Gruber zatytułowana Virtually Jewish (Gruber, 2002). Publikacja poświęcona jest zjawisku „nowej kultury żydowskiej” i stanowi kontynuację omawianej powyżej debaty. Na jej okładce widnieje wnętrze krakowskiej synagogi Izaaka udekorowane kartonowymi modelami Żydów w chasydzkich strojach. W polskim obiegu książkę - co do zasady - potraktowano w ten sam sposób jak esej Pinto. Polskojęzyczne wydanie ukazało się w 2004 roku, a tytuł przetłumaczono tak, aby nie zakłócić podniosłej atmosfery „spotkania kultur”: Odrodzenie kultury żydowskiej w Europie (Gruber, 2004). Okładkę, naturalnie, zmieniono również

Tekst Gruber, rozszerzający rozumienie praktyki „przestrzeni” na działania wykonywane w większości lub wyłącznie przez nie-Żydów, potraktowano jako źródło formuł i cytatów gotowych do użycia w ramach konstruowania uspokajającej opowieści o „dzielnicy”. Tytułowe pojęcie „wirtualności” użyte przez Gruber do nazwania przestrzeni „nieomal” żydowskich, lokujących się na pograniczu rekonstrukcji i inscenizacji, odczytane przez polskich interpretatorów stało się formułą zapewnienia o wiarygodności. Opatrzenie

7 Tytuł polskiego wydania książki Gruber w tłumaczeniu autorstwa Agnieszki Nowakowskiej nie zawiera już gry słów problematyzującej tytuł oryginału. Angielskie virtually Jewish tłumaczyć można zarówno jako: „wirtualnie/ pozornie żydowskie”, jak i „nieomal żydowskie”. Z kolei polski tytuł książki współbrzmi z nazwą Ruchu Odrodzenia Żydowskiego w Polsce, fantomowego, społecznego bytu-bohatera tryptyku Yael Bartany ...i zadziwi się Europa (2009). Obraz z okładki angielskiego oryginału zastąpiono fotografią autorstwa Andrzeja Strumiłły. Minimalistyczna kompozycja przedstawia mężczyznę (tym razem już nie kartonowego i w neutralnym stroju) stojącego pośrodku pustego, rozświetlonego wnętrza synagogi. Fotografia pochodzi z serii Medytacje. Synagoga Sejneńska. 1988. Okładkę zaprojektował Krzysztof Czyżewski (Gruber, 2004, s. 270). 
skądinąd problematycznego sformułowania „kultura żydowska” przymiotnikiem „wirtualna" prowadzi w ramach takiej lektury do ostatecznej, uspokajającej konkluzji: żydowska dzielnica uzyskuje w końcu swój właściwy kształt. Dzieje się to na przykład tak:

„Tysiące ludzi z uporem i energią pracuje, by przywrócić, odtworzyć, a właściwie: stworzyć na nowo «żydowską» Warszawę. Ich wiedza, wykształcenie, doświadczenie i kompetencje naukowe często są na bardzo wysokim poziomie. Fenomen «żydowskiego odrodzenia», któremu ton nadają w dużym stopniu nie-Żydzi, będący jego organizatorami, realizatorami oraz odbiorcami, tworzy nową formę kultury żydowskiej bez Żydów" (Dąbrowska, 2010).

Idea „wirtualności” stanowi dla polskiej opowieści o „żydowskiej dzielnicy” przyzwolenie na adaptacyjną dowolność. Jej komponenty - z sekwencją uzyskania „pożydowskiego mienia" na czele - poddaje się automatycznej reinterpretacji, a całą opowieść ostatecznie uwalnia od wszystkiego, co może uwierać.

Cóż innego mieszkaniec polskiego miasta wywieść może z końcowego fragmentu Odrodzenia kultury żydowskiej, brzmiącego tak: „Przestrzeń żydowska, według Diany Pinto, istnieje wciąż za sprawą pamięci, poczucia straty, tęsknoty, manipulacji. Sprawy żydowskie nabrały dzisiaj uniwersalnego znaczenia, są przedmiotem zainteresowań i studiów, atrakcją i rozrywką, wskrzesza się je, czasem traktuje instrumentalnie, a czasem uświęca. Ci, którzy próbują «przywrócić je do życia», czasem przywdziewają żydowski kostium, aspirując do przyjęcia związanej z nim tożsamości. Nierzadko to, co przywracają życiu, jest groteskowym żywym trupem" (Gruber, 2004, ss. 245-246). Ujęte w podobne ramy konceptualne warunki budowy „przestrzeni żydowskiej” odsuwają się ostatecznie od swoich założeń początkowych, a spojrzenie z zewnątrz - przyczyna niestabilności dotychczasowych wyobrażeń o „mieniu pożydowskim” - przynosi swoje własne rozwiązanie. Do urzeczywistnienia „przestrzeni” nie jest już potrzebna dekonstrukcja asymetrycznej relacji większość-mniejszość ani umożliwienie mniejszości współdecydowania o sferze publicznej - wystarczą mgliste koncepcje pamięci, poczucia straty i tęsknoty. Pamiętamy i tęsknimy, w najgorszym razie możemy przesadzić z manipulacją. Zjawi się wówczas żywy trup, ale wobec jego towarzystwa (czy też sąsiedztwa) „kultura polska” posiada pewne kompetencje. Adaptacyjne.

Zaistnienie tekstu Pinto i jego interpretacji zbiegło się w czasie z kulminacją polskich działań określanych mianem „przywracania pamięci żydowskich dzielnic”, a w swojej istocie polegających na zagospodarowaniu pozostałości przywłaszczonego mienia nieruchomego. Esej Diany Pinto, który w swoim uczciwym idealizmie postulował negocjowanie udziału europejskich Żydów w szeroko rozumianej europejskiej przestrzeni publicznej, natrafił na wspomnianą wcześniej językową próżnię wywołaną „odkryciem” żydowskiej dzielnicy i został przez jej polskich architektów przyjęty radośnie, niemniej w daleko niepełnym brzmieniu i obcej sobie postaci. Eseju tego nie potraktowano jako podstawy do namysłu nad możliwościami dialogu, ale jako budulec nowej opowieści

8 Fraza ta pochodzi z tytułu pokonferencyjnej publikacji, w której znajduje się też cytowany wcześniej esej Magdaleny Waligórskiej. Pełny tytuł książki brzmi: Przywracanie pamięci. Rewitalizacja zabytkowych dzielnic żydowskich w miastach Europy Środkowej (Murzyn-Kurpisz \& Purchla, 2008). 
o nim. Opatrzoną określeniami „wirtualna” czy „zapomniana” „przestrzeń żydowską” bez Żydów należałoby nazwać zgodnie ze stanem faktycznym: „przestrzenią pożydowską”. Dla polskich projektantów tej przestrzeni obecność drugiej strony debaty okazała się na tyle zbędna, że całkowicie wyręczyli ją z trudów współtworzenia „kulturowej agory, miejsca spotkania i dialogu"9. Pozostała sama terminologia, której wprowadzenie do polskiego obiegu okazało się dla naszego imaginarium nad wyraz korzystne. Szczególnie, że innej definicji „dzielnicy żydowskiej” chwilowo nie posiadamy. Byłoby zapewne o wiele prościej, gdyby rzecz dotyczyła jakiegoś pomnika (mamy w ich stawianiu sporą praktykę, budujemy ich całe konstelacje) ${ }^{10}$ czy innego upamiętnienia ofiar albo też muzeum. Mówimy jednak o realnie funkcjonującej tkance miejskiej, położonej w samym centrum naszych miast. 0 tkance, która mogła się okazać zupełnie nie nasza. Opatrzona etykietą „przestrzeni dialogu” - jakoś jednak funkcjonuje. W postaci centrum dialogu wirtualnego lub też agory pożydowskiej. Kolejność słów dowolna.

\section{plac}

Tak opowiadamy o polsko-żydowskim dialogu i jego przestrzeni. Opowiadamy innym, lecz przede wszystkim sobie samym. Za opowieścią podąża przestrzeń, gdyż montowana i sztukowana nieustannie opowieść o „miejscu dialogu” służy za konceptualną ramę kształtowania publicznej przestrzeni, za jej projekt architektoniczno-planistyczny. Proponowana $\mathrm{w}$ jego ramach metoda rekonfiguracji/adaptacji, przetestowana wcześniej podczas montażu fantazji na temat spotkania, staje się podstawą praktycznych działań w przestrzeni miasta ${ }^{11}$. Bo to o przestrzeń ostatecznie tu chodzi, o urbanistyczną substancję. O materiał budowlany, fizyczny i dotykalny. Skonstruowana ze skrawków opowieść

9 Planistyczną specyfiką opisywanej w dalszej części tego artykułu „pożydowskiej przestrzeni” dawnego getta warszawskiego, z niewielkimi wyjątkami zredukowanego do gruzu i substancji podstawowych, jest sytuacja przestrzenna, w której niewiele pozostaje do „zrewitalizowania”. W takiej sytuacji działają projektanci i planiści „warszawskiego Manhattanu” - korporacyjnej dzielnicy wieżowców rozciągającej się w śródmieściu Warszawy, od stojącego na miejscu Wielkiej Synagogi Błękitnego Wieżowca (1991, według projektu Jerzego Czyża, Andrzeja Skopińskiego, Jana Furmana, Lecha Robaczyńskiego, Marzeny Leszczyńskiej) do będącego obecnie w końcowym etapie budowy apartamentowca Cosmopolitan Twarda, znajdującego się na działce zajmowanej niegdyś przez synagogę Serdynera (2013, według projektu pracowni Murphy/Jahn; obiekt ten omawiam w dalszej części niniejszego tekstu). Warunki planistyczne dla tej części Warszawy stanowią rezultat sekwencji przesunięć własnościowych rozpoczętych tzw. dekretem Bieruta, na mocy którego wywłaszczono całość terenów pozostających w granicach Warszawy z 1945 roku (.Dekret z dnia 26 października 1945 r.”, 1945), i kontynuowanych zapoczątkowaną po 1989 roku serią projektów zagospodarowania okolicy placu Defilad. Pierwszą ważną koncepcją przekształcenia okolic placu w dzielnicę biurową był projekt Andrzeja Skopińskiego i Bartłomieja Biełyszewa, którym w 1992 roku przyznano pierwszą nagrodę w konkursie na koncepcję zagospodarowania ścisłego centrum Warszawy.

Mimo kontekstu planistycznego zapewniającego inwestorowi niemal pełną dowolność dysponowania przestrzenią publiczną, w ramach której retoryka „rewitalizacyjna” wydaje się nie mieć już znaczącego zastosowania, inwestor apartamentowca Złota 44 (2013, według projektu Daniela Libeskinda) reklamuje swój produkt słowami: „Mieszkalna funkcja budynku jest kluczem do zrozumienia roli tego projektu dla zmiany wizerunku miasta, a w szczególności rewitalizacji życia społecznego centrum Stolicy. Przy obecnej zabudowie biurowej warszawskiego downtown, życie zamiera tu w godzinach po pracy. Kiedy [...] do apartamentów wprowadzą się mieszkańcy, charakter okolic Pałacu Kultury i Nauki ma szansę zmienić się nie do poznania. Ulice centrum tętniące życiem do późnych godzin nocnych, nowe kafejki, restauracje i inne lokale rozrywki i usług, matki z dziećmi na spacerze, amatorzy joggingu zamiast pijaczków w pobliskim parku, czy nie tego potrzebuje Stolica?” („Mieszkalna funkcja budynku dla rewitalizacji życia w centrum miasta", 2010).

$10 \mathrm{Na}$ temat łączenia pomników w grupy pisze Elżbieta Janicka w książce Festung Warschau (Janicka, 2011).

11 W odniesieniu do opisywanej strategii zastosowanie mają pojęcia z dziedziny architektury i planistyki. Jak podaje Karta Burra, architektoniczny dokument konserwatorski rozszerzający zakres spisanej w 1964 roku Karty Weneckiej, „adaptacja” to „modyfikacja miejsca w taki sposób, aby odpowiadało obecnej lub proponowanej funkcji” (ICOMOS, 1999). 
o „przestrzeni spotkania polsko-żydowskiego” staje się tym samym rodzajem próby generalnej działań na lokalnym budulcu, na „pożydowskim mieniu”. Moment wykonania tej próby bywa ostatnim, w którym pamiętamy jeszcze, co mogłoby być jej celem. Odkąd przestrzeń opatrzona zostaje znakiem „wirtualnego miejsca spotkania”, najbardziej nawet bezinteresowne projekty konstruują ją do użytku jedynej strony dialogu posiadającej głos - strony polskiej większości. Analizując sekwencję powstania Dotleniacza, jednej z pierwszych interwencji podejmujących zadanie ustanowienia „miejsca spotkania”, chcę się przyjrzeć możliwościom negocjacji warunków takiego spotkania w środowisku, w którym „mienie pożydowskie” pozostaje dominującym komponentem przestrzeni fizycznej.

Jak więc budujemy nasze przestrzenie żydowskie? Nasze, bo nam samym - polskiej większości - opowiedziane? Z czego je budujemy i według jakich zasad? Odpowiedź oferowana przez miejską topografię Warszawy pod wieloma względami nie różni się od tej odnajdywanej na ulicach „polskich miasteczek”, o których w kontekście „mienia pożydowskiego” pisali cytowani wcześniej Grossowie (Gross \& Grudzińska-Gross, 2011, s. 146). Warszawa bywa „dziwnym miastem”, w którym nie to się widzi, na co się patrzy ${ }^{12}$, ale doświadczane wzrokowe komplikacje i zakrzywienia perspektywy to nic innego, jak przebitki obrazu spod skonstruowanego po 1945 roku widoku¹3. Efekty te ulegają wzmocnieniu wywołanemu skalą miasta, zmieniając je w rodzaj laboratorium, w którym wszystko, co wiemy o „mieniu pożydowskim”, staje się o wiele bardziej materialne, dosłowne, dotykalne. Na osiedlach skonstruowanych z gruzobetonowego pustaka „Muranów” wystarczy wyszukać ścianę z wykruszonym tynkiem. A na samym Muranowie, dzielnicy zbudowanej na gruzowym fundamencie wysadzonego getta, uważniej spojrzeć na trawnik w deszczowy dzień ${ }^{14}$. Skala wojennych zniszczeń i technologia odbudowy Warszawy uczyniła z ruchomego i nieruchomego „mienia pożydowskiego” realny fundament nowego początku, wzmacniany jeszcze przez wielkość i centralne usytuowanie dzielnic zamieszkiwanych przed Zagładą przez społeczności żydowskie.

Plac Grzybowski to samo centrum tego centrum. Z synagogą, żydowskim teatrem i z ulicą Próżną, „ostatnim nieodbudowanym po wojnie fragmentem miasta” (Raczyńska, b.d.). Tutaj w 2007 roku zostało zaprojektowane i zbudowane „miejsce spotkania”, Dotleniacz. Jego autorka, Joanna Rajkowska, pisała o nim tak:

„Projekt umożliwić ma spotkanie różnych społeczności, mieszkańców i gości placu Grzybowskiego. Jest próbą stworzenia na okres dwóch miesięcy latem tego roku utopijnej enklawy czystego powietrza, której centrum wyznaczy staw umieszczony pośrodku trawnika

12 Pojęcie „dziwnego miasta” pochodzi z książki Marty Zielińskiej o tym samym tytule (Zielińska, 1995). Pochodne warszawskich zjawisk związanych z widocznością i jej brakiem analizuje Magdalena J. Zaborowska w eseju Reading Transparent "Constructions of History" (Zaborowska, 2004).

13 Widokom śródmieścia Warszawy uzyskanym przez skierowanie wzroku we właściwe miejsce poświęcony jest projekt fotograficzny Elżbiety Janickiej i Wojciecha Wilczyka „Inne miasto” (Janicka \& Wilczyk, 2013).

14 Aby obserwować trawniki, należy mieć pewne doświadczenie. W zeszłym roku, w deszczowy dzień spotkałem sie z varsavianistą Januszem Sujeckim w jego biurze na ulicy Dzielnej. Tego dnia, podczas porannej drogi do pracy odnalazł na zieleńcach wypłukane przez deszcz: kutą klamkę okienną, fragment bakelitowego pudełka, kawałek szklanki ze zmętniałego, grubo ciętego kryształu, ceramiczną wtyczkę do kontaktu. Przedmioty te to "własność pożydowska - czyli niczyja” (Gross \& Grudzińska-Gross, 2011, s. 146), pozostawiona we wnętrzach budynków $w$ trakcie burzenia getta, a później przeoczona podczas powojennego zagospodarowania. 
na placu. Dotleniacz ma być oazą czystego, ozonowanego powietrza w samym sercu miasta, gdzie ludzie, przebywając koło siebie i oddychając tym samym generowanym powietrzem, będą mogli poczuć, że jednak możliwe jest «sąsiedztwo» - choćby tylko chwilowe. Ma to być miejsce spotkania bez negocjowania warunków, być może w ogóle pozbawione elementu komunikacji. Po prostu - wspólne siedzenie na ławce przy stawie i oddychanie natlenionym powietrzem" (Rajkowska, 2007b).

Natlenione powietrze to mgiełka unosząca się nad zaprojektowanym przez Rajkowską stawem, kilka metrów szerokim i głębokim na metr. Z ziemi usuniętej z niecki i wcześniej przebadanej przez archeologów utworzono nasyp, w którym ukryto urządzenia techniczne: ozonator i zamgławiacz. Urządzenia te służyły do wytwarzania wodnego aerozolu oraz do syntezy ozonu. Oba produkty wypuszczano następnie nad powierzchnię wody za pomocą kilku dysz. Dookoła stawu posadzono ozdobne krzewy, w samym jeziorku znalazły się nenufary, pływały w nim przyniesione przez publiczność ryby. Staw otoczyły kolorowe siedziska i zwykłe ławki. Projekt był tymczasową instalacją, zaprojektowaną na letnie miesiące. Otwarto go w lipcu 2007 roku (Pawełek, 2010a, s. 54). Było to „miejsce spotkania i dialogu" w pełnym znaczeniu. Spotykać się miały społeczności: mieszkańcy placu oraz jego goście. Towarzyszące Dotleniaczowi opracowania nie precyzują, kogo reprezentować miały te zbiorcze określenia. Twórczyni projektu podkreślała jednak planistyczną symetrię jego lokalizacji, wytyczonej pomiędzy kościołem Wszystkich Świętych a synagogą Nożyków ${ }^{15}$. Adresatami były zatem grupy symbolizowane przez największy warszawski zabytkowy kościół katolicki i jedyną w mieście synagogę. W okolicy są jeszcze wielopiętrowe bloki osiedli Grzybów i Za Żelazną Bramą wraz z ich mieszkańcami. Pojawiają się goście: odwiedzający kościół oraz turyści i izraelskie wycieczki młodzieżowe zwiedzające relikt warszawskiego getta. Pojęcie sąsiedztwa odnosi się więc do tych podmiotów. Jest to sąsiedztwo nietypowe, bo „pozbawione elementu komunikacji”, ale w zamian konceptualnie umiejscowione w teoriach sytuacjonizmu i site-specific art, dla których fizyczne uczestnictwo w zbiorowym "byciu tu i teraz" stanowi esencję działania ${ }^{16}$ (Pawełek, 2010b, ss. 26-28, 36).

15 Joanna Rajkowska opowiada o Dotleniaczu w swoim filmie: „Zdarzały się narzekania na to, że Dotleniacz jest zbyt blisko synagogi. Ale byli również tacy, dla których Dotleniacz był za blisko kościoła” (Rajkowska, 2007a).

16 Projekt Dotleniacz jest silnie umocowany w nurcie publicznej sztuki zlokalizowanej (site-specific art), kształtującej się w opozycji do instytucji galerii oraz związanych z nią procesów produkcji artystycznej i konsumpcji oraz do redukcji dzieła do „bezdomnego” towaru artystycznego, pozostającego w komercyjnym obiegu (Crimp, 1993, s. 17). Związany z tą lokalizacją postulat demontażu instytucji wyspecjalizowanego widza umieszcza odbiorcę sztuki zlokalizowanej, a więc i nieelitarnego odbiorcę Dotleniacza, w złożonej roli jednocześnie widza - uczestnika współautora - żywego komponentu instalacji.

Wynikający z takiego przesunięcia ról dyskurs, którego centralną częścią są (lub powinny być) głosy uczestniczących w Dotleniaczu mieszkańców Warszawy, wymaga osobnego opracowania. Reakcje odbiorców Dotleniacza przedstawione w towarzyszących mu krytycznych opracowaniach (m.in. Pawełek, 2010a) oraz cytowane przez samą autorkę (Rajkowska, 2007b, 2009) pojawiają się fragmentarycznie. Głosy te, przywołane przez sprofesjonalizowanego odbiorcę lub umieszczone w odautorskim komentarzu, nie oferują pełnego obrazu społecznych skutków umożliwionego „uczestnictwa”. Dla uzyskania takiego obrazu konieczna jest szersza analiza inicjatyw podjętych przez grupę widzów-uczestników Dotleniacza w celu jego odtworzenia latem 2008 roku. Osobnej analizy wymagają poruszane w tym kontekście kwestie wpływu mieszkańców na projektowanie miejskiej przestrzeni i na warunki jej użytkowania, na politykę przestrzenną i na strategie upamiętnienia. Istotny jest również wątek zdrowia i uzdrawiania, obecny w projekcie Dotleniacz i pojawiający się w komentarzach widzów-uczestników oraz w negocjacjach z przedstawicielami miejskiego samorządu. Wątek ten omawiam szerzej w dalszej części tego eseju. 
Dlaczego projekt powstał? Autorka wyjaśniła to już po jego zakończeniu, mówiąc:

„Reaguję mocno na miejsca chore, w których sieć relacji jest martwa bądź zastąpiona przez relacje pozorowane. [...] Mówiąc o miejscu chorym, myślę o Placu Grzybowskim. O wycieczkach izraelskich, które idą przez Plac Grzybowski, zupełnie nie wiedząc, gdzie są, ani czym w istocie jest prowadząca do placu ulica Próżna. O tym, jak ci Izraelczycy pompują swoje poczucie wspólnoty traumą i cudzą winą. Myślę o polskich starszych paniach, które patrzą na to wszystko podejrzliwie, o psach, co srają, gdzie popadnie i nikt po nich nie sprząta. O utrzymującym się wokót kościoła Wszystkich Świętych antysemickim smrodku księgarni Patriotycznej. Przypominają mi się fałszywi Żydzi z pejsami tańczący na festiwalu Singera i «koszerne» paszteciki wieprzowe sprzedawane w budce obok. Widzę biznesmenów idących przez ten plac do pracy w korporacjach i Deutsche Bank, który obsługuje tam swoich klientów. Figura papieża błogosławi to wszystko ze schodów kościoła, a harcerze składają kwiaty pod jednym z głazów upamiętniających kolejne polskie nieszczęścia" (Rajkowska, 2009, ss. 238-239).

\section{duszności}

Tak, to wszystko prawda, to wszystko tam jest. Nasze miasta są chore. Nasze miejsca, place, ulice i kamienice są chore. Przeniesioną w sferę urbanistyki metaforę choroby uważam za bardzo trafną. Uważam też, że należy się tej przenośni konsekwencja w użyciu oraz świadomość jej struktury: choroba to dysfunkcja ciała, to zaburzenie funkcjonowania jego substancji. W odniesieniu do miasta i miejskiej lokalizacji metafora ta wskazuje silnie na ich strukturalne komponenty: na projekt architektoniczny i planistyczną mapę. Jeśli szukać źródeł miejskiej „choroby” i jeśli lekarstwem na nią miałoby być zainstalowanie w centrum dysfunkcyjnej przestrzeni miejsca spotkania, służącego jej mieszkańcom i ich gościom, wypada spojrzeć na tę przestrzeń w rozumieniu możliwie dosłownym - na lokalizację Dotleniacza, warszawską dzielnicę Grzybów.

A historia Grzybowa, który posiada dziś nawet kilka domów starszych niż 50 lat i którego nazwa nie brzmi wcale tak samo, jak nazwa pustaka z mielonej cegły, to historia choroby, czy też może precyzyjniej: historia diagnozowania różnych chorób. Wspólnym ich objawem były zaburzenia układu oddechowego. Co zaś do ich przyczyn - przyczyny były architektoniczne i budowlane. Były nimi wkopane na metr czy więcej w ziemię domy tak samo jak Dotleniacz, z tą różnicą jednak, że miały adresy i numery. Niektóre mają je nadal. Historia dialogu i spotkania na Grzybowie to z jednej strony historia problemów z powietrzem, z drugiej historia najmów, wyprowadzek i przeprowadzek. Ma ona swój początek 1 maja 1825 roku, w dniu wprowadzenia w życie dekretu o włączeniu ulic Królewskiej, Marszałkowskiej i kilkunastu innych do grupy ulic egzymowanych ${ }^{17}$, czyli takich, z których Żydów usunięto i gdzie mieszkać im zakazano. Pomiędzy Królewską, Marszałkowską a dzisiejszym placem Dąbrowskiego mieszkali i pracowali żydowscy handlarze

17 Maria i Kazimierz Piechotkowie podają zgodnie z dekretem z 1821 roku inne nieco brzmienie wspomnianego terminu: ulice eksprymowane (Piechotka \& Piechotka, 2004, s. 271). O wypędzeniu społeczności żydowskiej na Grzybów pisze Stanisław Herbst w Ulicy Marszałkowskiej (Herbst, 1978, ss. 61-62). Treść obwieszczenia o tej eksmisji opublikowano w „Gazecie Warszawskiej” (nr 138) z 30 sierpnia 1823 roku, s. 1911. 
żelazem i starzyzną. Wcześniej wynajmowali składy i mieszkania w przybudówce pałacu Pociejów, w rejonie dzisiejszego placu Teatralnego. Okolicę tę jednak wyegzymowano już w 1808 roku, eksmitując jej mieszkańców na ulice Królewską i Marszałkowską, skąd 1 maja 1825 roku przesiedlono ich na ulicę Bagno na Grzybowie ${ }^{18}$. Przy ulicy Bagno były trzy szerokie podwórza, które określano utrwaloną wcześniej nazwą Pociejów. Targ żelazny pozostał tam przez półtora stulecia, do lat sześćdziesiątych XX wieku. Tylko wtedy właściciele byli już inni.

Co do problemów oddechowych - plac Grzybowski wywołuje je od maja 1825 roku. Pierwszym, który doświadczył ich w tak wielkim natężeniu, że nieuniknionym stało się złożenie raportu z objawów, był Aleksander Niewiarowski, młody dziennikarz "Gazety Warszawskiej"19. Odkąd pojawił się na placu Grzybowskim jesiennego dnia 1854 roku, jego problemy oddechowe pogłębiały się z każdym krokiem. Jak pisał:

„[M]inąwszy szeregi sklepów zapchanych kawałami starego żelastwa lub mosiądzu i łachmanami poszarpanych zaprzęgów - dochodzi się do rogu ulicy Bagno. - Z samego nazwiska pojmujecie jaka to musi być ulica! Lecz minąwszy bagno, przez trzy równoległe bramy wchodzi się do jeziora błota i nieczystości. [...] Ktokolwiek z ludzi nieobeznanych z miastem i drobnymi tajemnicami jego handlu wejdzie raz pierwszy na Pociejów, nie zdoła pojąć, jakim sposobem można oddychać zgniłym, wilgotnym i cuchnącym powietrzem, które napełnia cały ten kwadrat" (Niewiarowski, 1855, ss. 1-2).

Niewiarowskiemu śmierdzi całe podwórze - „cmentarz, w którym grzebią zwłoki starych mebli, sukien, żelastwa”, śmierdzi „żydowski, tandetny towar Pociejowa”, śmierdzi w końcu lichwiarski sposób, jakim handlarze weszli w jego posiadanie ${ }^{20}$ (Niewiarowski, 1855 , s. 2). Jego wstręt jest biologiczny i cielesny, jest i moralny. Spisana przez niego relacja to pierwszy w ogóle opis placu Grzybowskiego, a zarazem jeden z wcześniejszych opisów reguł „sąsiedztwa”, a więc sposobu, w jaki zmysły uczestnika polskiej większości reagowały na „żydowską dzielnicę”.

Częstotliwość pojawiania się opowieści o duszącym charakterze Grzybowa rosła w miarę, jak okolice placu przekształcały się z na wpół wiejskiego przedmieścia w część

18 Eksmisję na ulicę Bagno przeprowadzono wówczas częściowo. Jak podaje Herbst, w spisie ludności z 1829 roku na posesji Łubieńskich przy ulicy Królewskiej zarejestrowano jeszcze 433 Żydów (Herbst, 1978, ss. 61-62). Ta sama publikacja podaje powtarzana wielokrotnie w późniejszych opracowaniach informacje o założeniu targu Pociejów na ulicy Bagno dopiero w roku 1864 (Herbst, 1978, s. 78). W rzeczywistości rok 1864 to data ostatecznej likwidacji targowiska pomiędzy ulicą Królewską a dzisiejszym placem Dąbrowskiego (które zwano „starym Pociejowem”), natomiast targ na ulicy Bagno istniał już przed rokiem 1825. „Kurier Warszawski” z 8 stycznia 1825 roku informował o sprzedaży dwóch kamienic na ulicach Bagno i Zielnej, „z placem i budami przez Izraelitów żelastwem handlujących wynajętymi” („Kurier Warszawski” z 7-8 stycznia 1825, s. 26).

19 O Niewiarowskim i jego tyle obiecującej, co niespełnionej zawodowej biografii pisał w pierwszym tomie antologii warszawskiego felietonu Jan Józef Lipski. Przy biogramie Niewiarowskiego autor umieścił w pełniejszym brzmieniu cytowany poniżej artykut (Lipski, 1973, ss. 85-90).

20 Niewiarowski opisuje poddasze zaadaptowane na sklep, na które udał się w poszukiwaniu używanych sprzętów domowych. Wyobraża on sobie, że komplet mebli zachwalany przez żydowskiego handlarza należał wcześniej do polskiej rodziny i został sprzedany z konieczności wywołanej niespodziewaną śmiercią jej członka (Niewiarowski, 1855, s. 2).

Oskarżenia o lichwę i zaniżanie cen wysuwane pod adresem handlarzy używanymi meblami i starzyzną z placu Grzybowskiego pojawiały się i później w ówczesnej warszawskiej prasie (np. artykuł W. Małagowskiego, Znaczenie $i$ karygodność lichwy, „Gazeta Sądowa Warszawska” nr 11 z 2 czerwca 1873 roku, s. 81-85, oraz jego anonimowa kontynuacja w „Kurierze Warszawskim” nr 207 z 9 września 1876 roku, s. 1). Osobno w roku 1859 „Gazeta Warszawska” prowadziła antysemicką kampanię prasową, znaną później jako „wojna żydowska”, której centralnym elementem były oskarżenia o lichwę. Na ten temat piszą m.in. Bartoszewicz, 1913; Moch, 2008. 
śródmiejskiej Warszawy. Częstotliwość rosła jeszcze bardziej, odkąd przy nieomal sąsiednich Alejach Jerozolimskich poprowadzono pierwszą w Warszawie linię kolejową, włączając Grzybów z przyległościami do ścisłego centrum i zmieniając okolice ulic Żelaznej i Twardej w dzielnicę przemysłowo-robotniczą. Fizyczna substancja żydowskiej dzielnicy: „nadzwyczajnie nieczyste powietrze w domu zwanym Pociejów”21 (nazywanym gdzie indziej wprost „cuchnącym”22) objawia się wówczas głównie w sferze pozawzrokowej. Uporczywe powracanie „złego zapachu” sygnalizuje dokonującą się wówczas fuzję dwóch antyżydowskich opowieści: starego mitu foetor Judaicus, nieusuwalnego „żydowskiego smrodu" (por. Smith, 2012; Zafran, 1979), który łączył się z nowoczesną dystopijną narracją, wedle której przemysłowo-robotnicza dzielnica to źródło fizycznych zagrożeń: epidemii i rewolucji23.

Wszystkie te komponenty nowoczesnych miejskich fobii znane są i z pozostałych europejskich miast, rozwijających się w przemysłowe metropolie od lat sześćdziesiątych XIX wieku. Splot modernizacyjnych niepokojów z przednowoczesnym i przedwizualnym językiem etnicznego wykluczenia jest jednak lokalną specyfiką miast polskich. Splot ten, dokonujący się na warunkach ściśle materialnego, dosłownego rozumienia figury powietrza i zapachu, wskazuje na żydowską własność jako na źródło miejskich nieszczęść.

21 W lipcu 1873 roku „Kurier Warszawski” informował o „nadzwyczajnie nieczystym powietrzu na ulicy Bagno, a mianowicie w domu zwanym Pociejów”, miesiąc później powiadamiał dodatkowo o tamtejszych „kałużach i śmieciowiskach” („Kurier Warszawski” nr 171 z 31 lipca 1873 roku, s. 2, oraz nr 184 z 28 sierpnia 1873 roku, s. 2).

22 Tak „Prawda. Tygodnik polityczny, społeczny i literacki” nr 40 z 7 października 1893 roku, s. 478.

23 Zagrożenie epidemiczne przedstawiano za pomocą archaicznej, lecz popularnej niemal do końca XIX wieku, teorii miazmatów. Objaśniała ona, że nawiedzające przeludnione miasta epidemie wywołuje „złe powietrze”, pochodzące z gęsto zabudowanych kwartałów. Więcej zob. Corbin, 1986; Halliday, 2001; Thorsheim, 2006.

Jak pisze Joanna Tokarska-Bakir, tradycją wynikającą z obawy przed „złym” zapachem wywoływanym sąsiedztwem getta był „nakaz przenoszenia synagog na pewną odległość od kościołów” (Tokarska-Bakir, 2008, s. 353). Taką intencją kierowała się Gabriela Zabiełło, fundatorka działki pod budowę kościoła Wszystkich Świętych na placu Grzybowskim. W dniu konsekracji budowli warszawski tygodnik literacki tak pisał o motywacjach ofiarodawczyni:

„Nowy dom Boży przybył Warszawie; w dzielnicy upośledzonej pod względem wpływów moralnych na lud chrześcijański, w ognisku handlu, wśród chederów i przekupniów - wyrósł ponad wielkie gmachy krzyż, znak zbawienia w złej i lepszej doli. Przed kilkunastu laty dzielnica stolicy, zwana Grzybowem, była nieprzerwanym szeregiem szynków; wszystkie one należąc do izraelitów nęciły pospólstwo, które zapracowany grosz zamieniało w nich na rozpustę. W to piekło zstąpiła czcigodna pani polska, śp. Gabryella hr. Zabiełłowa, a przerażona widokiem upadku, postanowiła ratować nieszczęśliwych. Nie poprzestając na ubolewaniach, czcigodna pani wzięła się do dzieła: ofiara jej była fundamentem” („Biesiada Literacka” nr 410 (16) z 9 listopada 1883 roku, s. 290).

Szczegóły tej decyzji podaje kronika budowy kościoła: „Zastanawiano się więc nad tym, czy nie byłoby lepiej sprzedać $w$ ręce prywatne darowaną na rzecz kościoła posesję i z osiągniętego z tej sprzedaży funduszu kupić inny, mniejszej przestrzeni i tańszy plac, w dalszym przedłużeniu ulicy Twardej, co jak sądzono, byłoby rzeczą właściwą jeszcze z tego powodu, że darowana posesja, jako położona w części miasta gęsto zaludnionej ludnością żydowską, nie bardzo się nadaje pod budowę katolickiej świątyni. Propozycje te i zarzuty hr. Zabiełło z energią i stanowczością odpierała. O zamianie w jakikolwiek bądź sposób darowanej na kościół posesji ani słyszeć nie chciała [...]. Sądziła również, że będzie najwłaściwiej, gdy w tym punkcie miasta chwała Boża rozbrzmiewać będzie i ukracać zgorszenie, jakie się tu z powodu licznych okolicznych szynkowni zagnieździło" (Gagatnicki, 1893, ss. 16-17). Poza tą wzmianką kronika nie wspomina o Grzybowie i jego żydowskiej społeczności. W jeszcze bardziej oszczędny sposób wypowiada się na jej temat Jarosław Zawadzki w opracowaniu o kościele Wszystkich Świętych (Zawadzki, 1997).

Pojawiające się w cytowanym powyżej artykule określenie „chedery” odnosić się może zarówno do prywatnej szkoły męskiej prowadzonej przez Aarona Schwartzenberga w sąsiadującym z kościołem domu przy placu Grzybowskim 1 (por. „Kurier Warszawski” nr 194 z 2 września 1871 roku, s. 4), jak i do szkół religijnych połączonych z domami modlitwy, znajdujących się w oficynach kamienic po przeciwnej stronie ulicy Twardej.

Codzienne funkcjonowanie kościoła Wszystkich Świętych rozumiano również jako sposób walki z „socjalistyczną agitacją”. Ksiądz Marceli Godlewski, późniejszy Sprawiedliwy, a wówczas organizator katolickiego ruchu robotniczego, który objął grzybowską parafię w 1914 roku, tak wykładał priorytety swojej misji: „Przestrzegać przed nikczemną, a niezmiernie szkodliwą agitacją socjalistyczną, znajdującą się pod komendą żydowsko-pruską. Informować, służyć radą i wskazówką wszystkim potrzebującym pomocy i wsparcia” („Kuryer dla Wszystkich” nr 1 z 23 sierpnia 1914 roku, s. 1). 
Stanowi narrację o cechach eliminacyjnych, gdyż implikuje nieusuwalność „złego zapachu" dzielnicy żydowskiej, dającego się tylko tymczasowo łagodzić zabiegami dezynfekcji i asenizacji24, a usuwalnego tylko wraz z usunięciem faktu własności²5.

\section{nawrót}

W ramach projektu Dotleniacz powietrze powraca do opowieści o placu Grzybowskim. Pojawia się zarówno w roli centralnego elementu kompozycyjnego projektu, jak i głównego nośnika metafory mającej umożliwiać spotkanie. Pobierane wprost z placu Grzybowskiego, znad powierzchni wody wypełniającej staw, powietrze to poddawane było przed ponownym wypuszczeniem procesowi ozonowania, dokonywanego za pomocą specjalistycznego urządzenia. Według specyfikacji, „produkcja ozonu oparta jest na zasadzie cichego, elektrycznego wyładowania w zmiennym polu wysokiego napięcia, które oddziałuje na strumień czystego, suchego tlenu lub powietrza z otoczenia", natomiast sam ozon „jest jednym z najsilniejszych utleniaczy i znakomicie nadaje się do uzdatniania wody, oczyszczania ścieków, utleniania produktów przemysłowych oraz oczyszczania powietrza. Stosowanie ozonu jest szczególnie ekologiczne, gdyż zanieczyszczenia, barwa, zapachy i mikroorganizmy redukowane są bez powstania szkodliwych produktów ubocznych” („Dezynfekcja wody metodą ozonowania”, b.d.) ${ }^{26}$. Aseptyka i dezynfekcja. Asenizacja i sterylizacja. Ten ostatni termin miał być szczególnie odpowiedni, gdyż według Joanny Rajkowskiej funkcjonuje on w języku polskim jako słowo znacznie silniejsze niż „oczyszczanie”. „Dlatego użyłam go w filmie [podsumowującym instalację - K.M.] ${ }^{27}$, bo pomyślałam, że oczyszczanie to za mało" - stwierdziła autorka w trakcie debaty organizowanej przez kuratora projektu, chwilę później dodając: „chciałam sterylizować, likwidować

24 Warszawskie Towarzystwo Asenizacyjne założono w 1883 roku. Kilka miesięcy później otrzymało pierwsze zlecenia: „Ulice przylegle do Muranowa, a w szczególności Dzika, Nalewki, Świętojerska i Franciszkańska posiadają jak najsroższe warunki higieniczne. Domy, schody, sienie, podwórza i śmietniki stanowią źródła zaraźliwego powietrza. Na podwórzach wielka liczba najróżnorodniejszych odpadków zdaje się być umyślnie porzuconą dla wydzielania miazmatów uniemożliwiających oddychanie. [...] Aparaty towarzystwa asenizacyjnego odbywają czynności bez względu na porę dnia. Wzmiankowana dzielnica winna zwrócić szczególną uwagę władzy” („Kurier Warszawski” nr 197a z 18 lipca 1884 roku, s. 2).

I dalej następnego dnia: „Do kategorii ulic znajdujących się w najgorszych warunkach sanitarnych i wymagających szczególnej opieki policji zdrowia należy także ulica Twarda. [...] Jako handlowa i mocno zaludniona wiele pozostawia do życzenia i w niczym nie ustępuje wymienianym już przez nas swoim sąsiadkom, jak Grzybowska, Pańska, Bagno itp.” („Kurier Warszawski” nr 198a z 19 lipca 1884 roku, s. 2).

25 Wschodnia część placu Grzybowskiego wraz z ulicą Próżną i Pociejowem pozostawały w ramach okupacyjnego getta tylko pięć miesięcy. W marcu 1941 roku tablice z ostrzeżeniem o „obszarze zagrożonym epidemią” przesunięto z ulicy Próżnej w głąb placu. Jak pisze Emanuel Ringelblum, stało się to na skutek przekupienia hitlerowskiego komisarza getta przez polskiego właściciela jednego ze składów żelaznych przy ulicy Próżnej (Ringelblum, 1983, s. 249). Podczas akcji likwidacyjnej 6 sierpnia 1942 roku hitlerowcy, zanim zapędzili mieszkańców „małego” getta na Umschlagplatz, zgromadzili około 40 tysięcy osób na placu Grzybowskim (Blum-Bielicka, 1961, s. 73; Ringelblum, 1983, s. 606). Trzy dni później, 9 sierpnia, ogłoszono opróżnienie „małego” getta z reszty mieszkańców, z terminem wykonalności jeden dzień. Opuszczone mienie ruchome rozszabrowano, a nieruchome zajęli nowi mieszkańcy (Engelking \& Leociak, 2001, s. 107).

26 Z powodu właściwości utleniających ozon występujący w niskich warstwach atmosfery traktowany jest jako zanieczyszczenie powietrza i substancja niepożądana. Prowadzono badania korelacji występowania ozonu z zaburzeniami w rozwoju roślin i funkcjonowaniu ekosystemów oraz z wystepowaniem krótko- i długoterminowych negatywnych objawów w układzie oddechowym ludzi (Folinsbee, Bedi, \& Horvath, 1980; Galizia \& Kinney, 1999). Stężenie ozonu w miejskim powietrzu mierzą stacje pomiaru zanieczyszczeń; najbliżej placu Grzybowskiego znajduje się taka stacja na ulicy Kruczej (Trebińska \& Barańska, 2008, s. 31).

27 Mowa o filmie J. Rajkowskiej Dotleniacz. Plac Grzybowski w Warszawie (Rajkowska, 2007a). 
symbolicznie toksyny złej pamięci, niechęci, złogów i zajadłości, których przyczyn nikt już nawet nie pamięta” (Pawełek, 2010a, s. 234,235).

Powietrze powraca w podwójnej postaci: w roli czynnika zagrażającego i zanieczyszczającego, nośnika toksyny oraz środowiska nasycanego środkiem dezynfekcyjnym i sterylizującym, służącym do neutralizacji zanieczyszczenia. Obiekt działań sterylizacyjnych to zarówno powietrze unoszące się nad placem, jak i woda wypełniająca wykop, w której również rozpuszczano ozon. Zważywszy na obecność metaforyki medycznej zarówno w dyskusjach dotyczących Dotleniacza, jak i w samej jego nazwie ${ }^{28}$, przywrócenie placowi Grzybowskiemu tego rodzaju powietrznej symboliki określić należy raczej mianem nawrotu. Słowo to wydaje się odpowiednie również dlatego, że opisywana praktyka leczy chorobę za pomocą jej samej.

Aseptyczne i dezynfekcyjne działanie ozonu w ramach projektu Rajkowskiej występuje w roli symbolu oczyszczenia atmosfery potencjalnego spotkania Polaków i Żydów z tego, co spotkanie to uniemożliwia. Nie jest celem tej analizy rozpatrywanie stosowności użycia metafory sterylizacji w przestrzeni, dla której oczyszczenie stanowi składową jednego z bardziej dotkliwych schematów służących - zależnie od historycznego kontekstu - wypchnięciu lub eliminacji. Zasadne wydaje się jednak postawienie pytania o skutki stosowania środka dezynfekującego rozumianego, jak pokazują reakcje na Dotleniacz, w równym stopniu symbolicznie, jak dosłownie ${ }^{29}$.

Skutkiem tego jest eliminacja werbalnych komponentów języka, za pomocą których można formułować potrzebę użytkowania przestrzeni różnorako motywowaną - pamięcią, interesem, tożsamością. Autorka rozumiała „utlenienie” artykulacji jako zjawisko korzystne, mówiąc: „zobacz, jak ci ludzie tam siedzą. W tym projekcie jest zawarta głęboka niewiara $w$ to, że da się coś wyjaśnić, że da się porozumieć, że da się coś przegadać. I to jest zwycięstwo Dotleniacza. Że ludzie nie rozmawiają" (Rajkowska, 2010, s. 72). Problem w tym, że oczyszczenie dokonuje się w sposób gruntowny i niewiele po nim zostaje. W pierwszej kolejności utleniana jest możliwość wyrażania tożsamości mniejszościowej, co celnie uchwyciła Monika Bakke, pisząc: „Usytuowanie Dotleniacza, jego specyficzne miejsce w dawnej żydowskiej dzielnicy Warszawy uwikłane jest w bogaty kontekst przeszłości. [...] Dotleniacz nie należy do przeszłości, bowiem, co trzeba szczególnie podkreślić, produkuje teraźniejszość - ma sens tylko na żywo - wspomagając oddychanie" (Bakke, 2010, s. 138). Nieścisłość tej oceny zawiera się w jednym szczególe: „specyficzne miejsce”,

28 Nazwa projektu niesie medyczne konotacje - aluzyjnie tkwią w nazwie polskiej, a silniej brzmią w równolegle stosowanym angielskim tytule (Oxygenator), przywołującym skojarzenia z intensywną terapią i złożonymi zabiegami chirurgicznymi. Źródłem polskiej nazwy projektu jest czasownik „dotleniać”, który zgodnie ze słownikiem znaczy tyle, co „dostarczyć dodatkową ilość tlenu”. Forma zwrotna „dotleniać się” tłumaczona jest jako „być dotlenianym, wdychać dodatkową, dostateczną ilość tlenu, nasycać się tlenem w dostatecznym stopniu” (Doroszewski, 1977). Angielski tytuł instalacji jest słowem oznaczającym komponent tzw. płuco-serca, urządzenia przejmującego funkcjonowanie układów oddechowego i krwionośnego w czasie operacji chirurgicznych lub w przypadkach nagłej niewydolności tych układów (Stammers \& Throwbridge, 2008).

29 Zarówno komentatorzy pracy, jak i jej publiczność szeroko podjęli zdrowotno-higieniczną metaforykę. W komentarzach pojawiały się wątki uzdrowiska, sanatorium i miejskiego ogrodu (Fudala, 2010, ss. 206-207; Warsza, 2010, s. 169), natomiast cytowani widzowie-uczestnicy mieli mówić o zawartości stawu jako o „takiej specjalnej wodzie, która jest zdrowa i którą wszyscy tu oddychamy”. Mieli być też przekonani o jej leczniczych właściwościach (Rajkowska, 2009, s. 198). 
na które składa się warszawska synagoga i przyległe do niej centrum społeczności żydowskiej, bywa dziś używane i posiada swoich użytkowników. Co do reszty, badaczka ma niestety rację. Niezupełnie wiadomo, jak miałaby się tu odbywać realizacja postulatu Diany Pinto dotyczącego negocjacji uczestnictwa w publicznej przestrzeni, dokonywanej na równych prawach pomiędzy osobami określającymi się jako Żydzi a polską większością. Pytanie o możliwość i sposób takiej negocjacji wydaje się nawet nieco nie na miejscu w odniesieniu do instalacji artystycznej umożliwiającej „spotkanie” w fenomenologicznie czystej postaci „bycia w przestrzeni”. Sądzę jednak, że warto to pytanie zadać, choćby z przyczyny zupełnego braku deklarowanej symetrii w „utlenianiu”: terytorializacja społeczności użytkującej Dotleniacz odbywała się w ramach jasno artykułowanych zasad polskiej większości. Złożyły się na nią - na przykład - spotkania organizowane na plebanii kościoła Wszystkich Świętych. Nikt z gminy żydowskiej na spotkaniu takim niestety się nie zjawił. Zanotowano natomiast komentarz jednej z jego uczestniczek, wskazującej na okolice synagogi i sugerującej wykorzystanie Dotleniacza do spowodowania, „żeby oni wreszcie tam posprzątali, bo teraz to już jest nasza wspólna przestrzeń, wszyscy w niej jesteśmy" (Pawełek, 2010a, s. 236).

\section{asenizacja}

Pytanie o możliwość i warunki negocjacji staje się jeszcze bardziej istotne - $\mathrm{i}$ jeszcze mniej stosowne - w odniesieniu do placu Grzybowskiego w jego obecnej postaci. Jest to postać sterylna w najwyższym stopniu, bo tylko mianem sterylizacji da się określić proces, który nastąpił po demontażu projektu Rajkowskiej. Umożliwił on zbudowanie 44-piętrowego apartamentowca o nazwie Cosmopolitan Twarda kilka metrów od budynku synagogi Nożyków, adaptację kamienicy przy Próżnej 7-9 na biurowiec nazwany Le Palais oraz planowanie budowy kolejnego wysokościowca na miejscu Teatru Żydowskiego. $\mathrm{Na}$ środku obłożonego średniej jakości granitem skweru, pośrodku placu Grzybowskiego, znajduje się dziś geometryczne jeziorko z dyszami wypuszczającymi mgiełkę ${ }^{30}$. Mgiełka ta już nie zawiera ozonu, ale sterylna przestrzeń już go nie wymaga. Korporacyjna aranżacja placu Grzybowskiego stanowi bowiem „przestrzeń pożydowską” w swoim finalnym stadium: oczyszczoną i odkażoną, zbudowaną z mienia pożydowskiego i na tym mieniu oraz zaadaptowaną według formuły „przestrzeni żydowskiej”, z której wątek współuczestnictwa uprzednio usunięto. Rusztowania i dekoracje sklejone z opowieści o „przestrzeni dialogu", cała ta scenografia umożliwiająca niewidzenie i niepatrzenie, po ukończeniu prac budowlanych nie będzie już potrzebna. Za dialog wystarczy w najlepszym razie kilka dni festiwalu Warszawa Singera.

30 W rozstrzygniętym 10 grudnia 2008 roku konkursie na „koncepcję modernizacji przestrzeni placu Grzybowskiego ze szczególnym uwzględnieniem skweru" pierwszą nagrodę zdobył zespół autorski Pleneria s.c. w składzie: Dariusz Malinowski, Agata Ciesielska, Agata Czarnecka, Monika Radkiewicz, Michał Jaworski (por. Konkurs na koncepcję modernizacji przestrzeni placu Grzybowskiego, Oddział Warszawski Stowarzyszenia Architektów Polskich, SARP 2008, http://www.warszawa.sarp.org.pl/pokaz.php?id=5287).

W oficjalnym komunikacie ogłaszającym wyniki konkursu Urząd Miasta zapowiedział wówczas: „rewitalizacja placu Grzybowskiego wkracza w kolejny etap” (por. Plac Grzybowski za rok, Wydział Prasowy Urzędu Miasta Stołecznego Warszawy z 2008 roku; http://www.um.warszawa.pl/sites/default/files/20288PI_GRZ_Informacja\%20prasowa.pdf). 
A pytanie o współuczestnictwo, o jego możliwości i warunki? Wobec perspektywy rychłego ukończenia Cosmopolitan Twarda, który współuczestnictwo w przestrzeni definiować będzie w radykalnie inny sposób, do uświadomienia sobie zasadności powyższego pytania potrzebne będą pytania pomocnicze:

Kto obok kogo usiądzie?

Gdzie usiądzie i na czym?

Kto z kim będzie sąsiadować?

Czy będzie czym oddychać?

\section{Bibliografia}

Adamczyk-Garbowska, M., \& Polonsky, A. (2001). Contemporary Jewish Writing in Poland: An Anthology. Lincoln: University of Nebraska Press.

Bakke, M. (2010). Respiracja. Obieg (Dotleniacz / Oxygenator), (1-2 (81-82)), 136-139.

Barańczak, S., \& Cavanagh, C. (Red.). (1991). Polish Poetry of the Last Two Decades of Communist Rule: Spoiling Cannibals' Fun. Evenston: Northwestern University Press.

Bartoszewicz, K. (1913). Wojna żydowska z roku 1859. Początki asymilacyi i antysemityzmu. Warszawa: Gebethner i Wolff.

Blum-Bielicka, L. (1961). Szkoła Pielęgniarstwa przy Szpitalu Starozakonnych w Warszawie (1923-1943). Wspomnienia. Biuletyn ŻıH, 40.

Corbin, A. (1986). The Foul and the Fragrant: Odor and the French Social Imagination. Cambridge (Mass.): Harvard University Press.

Crimp, D. (1993). On the Museum's Ruins. Cambridge (Mass.): MIT Press.

Dąbrowska, K. (2010). Żydowska i „żydowska” Warszawa - dwa oblicza stolicy. Opcit, (40). Pobrano z http://opcit.pl/teksty/zydowska-i-zydowska-warszawa-dwa-oblicza-stolicy

Dekret z dnia 2 marca 1945 r. o majątkach opuszczonych i porzuconych. (1945). Dziennik Ustaw, 9 (poz. 45), 55-59.

Dekret z dnia 26 października 1945 r. o własności i użytkowaniu gruntów na obszarze m. st. Warszawy. (1945). Dziennik Ustaw, 50(poz. 278-279), 434-435.

Dekret z dnia 8 marca 1946 r. o majątkach opuszczonych i poniemieckich. (1946). Dziennik Ustaw, 13 (poz. 87), 165-172.

Dezynfekcja wody metodą ozonowania. (b.d.). erem.com.pl. Pobrano z http://erem.com.pl/ dezynfekcja-wody-metoda-ozonowania

Doroszewski, W. (Red.). (1977). Stownik języka polskiego PWN. Warszawa: PWN.

Engelking, B., \& Leociak, J. (2001). Getto warszawskie. Przewodnik po nieistniejącym mieście. Warszawa: Wydawnictwo IFiS PAN.

Folinsbee, L. J., Bedi, J. F., \& Horvath, S. M. (1980). Respiratory Responses in Humans Repeatedly Exposed to Low Concentrations of Ozone. The American Review of Respiratory Disease, (121 (3)), 431-439.

Fudala, T. (2010). Wychowywanie przez dotlenianie. Obieg (Dotleniacz / Oxygenator), (1-2 (81-82)), 206-213.

Gagatnicki, A. (1893). Kościót Wszystkich Świętych w Warszawie. Warszawa: Drukarnia Franciszka Czerwińskiego. 
Galizia, A., \& Kinney, P. L. (1999). Long-Term Residence in Areas of High Ozone: Associations with Respiratory Health in a Nationwide Sample of Nonsmoking Young Adults. Environmental Health Perspectives, 107(8), 675-679. doi:10.1289/ehp.99107675

Gross, J. T., \& Grudzińska-Gross, I. (2011). Złote żniwa. Rzecz o tym, co działo się na obrzeżach zagłady Żydów. Kraków: Znak.

Gruber, R. E. (2002). Virtually Jewish: Reinventing Jewish Culture in Europe (1. wyd.). Berkeley: University of California Press.

Gruber, R. E. (2004). Odrodzenie kultury żydowskiej w Europie. (A. Nowakowska, Tłum.). Sejny: Pogranicze.

Halliday, S. (2001). Death and Miasma in Victorian London: an Obstinate Belief. BMJ, 323(7327), 1469-1471. doi:10.1136/bmj.323.7327.1469

Herbst, S. (1978). Ulica Marszałkowska. Warszawa: Książka i Wiedza.

ICOMOS. (1999). The Burra Charter. Australia: ICOMOS.

Janicka, E. (2011). Festung Warschau. Warszawa: Wydawnictwo Krytyki Politycznej.

Janicka, E., \& Wilczyk, W. (2013). Inne miasto. Warszawa: Zachęta.

Janicka, E., \& Żukowski, T. (2012). Przemoc filosemicka. Studia Litteraria et Historica, 1.

Pobrano z http://www.slh.edu.pl/content/przemoc-filosemicka

Krall, H. (1985). Sublokatorka. Paryż: Libella.

Lipski, J. J. (1973). Warszawscy „Pustelnicy” i „Bywalscy” (T. 1: Felietoniści i kronikarze 1818-1899). Warszawa: PIW.

Meng, M. (2011). Shattered Spaces: Encountering Jewish Ruins in Postwar Germany and Poland. Cambridge (Mass.): Harvard University Press.

Mieszkalna funkcja budynku dla rewitalizacji życia w centrum miasta. (2010, maj 11). Zlota44. Pobrano z http://www.zlota44blog.pl/?p=105

Moch, M. (2008). „Światło wieku przełamie zawziętości i przesądy” - publicystyka Ludwika Lublinera i Joachima Lelewela w kontekście „wojny żydowskiej” 1859 r. Pamiętnik Literacki, 2, 23-32.

Murzyn-Kurpisz, M., \& Purchla, J. (Red.). (2008). Przywracanie pamięci. Rewitalizacja zabytkowych dzielnic żydowskich w miastach Europy Środkowej. Kraków: MCK.

Niewiarowski, A. (1855). Gazeta Warszawska, (5 (93)), 1-2.

Pawełek, K. (Red.). (2010a). Dotleniacz / Oxygenator (Obieg 1-2).

Pawełek, K. (2010b). Oddech (bez)warunkowy. Dotleniacz / Oxygenator (Obieg), (1-2 (81-82)), 26-39.

Piechotka, M., \& Piechotka, K. (2004). Oppidum Judaeorum: Żydzi w przestrzeni miejskiej dawnej Rzeczypospolitej. Warszawa: Krupski i s-ka.

Pinto, D. (1999). The Third Pillar? Toward a European Jewish Identity. Golem: Europäisch-jüdisches Magazin, 1. Pobrano z http://www.hagalil.com/golem/jewish-identity/pillar.htm

Raczyńska, M. (b.d.). Więcej tlenu. Joanna Rajkowska. Pobrano z http://www.rajkowska.com/pl/teksty/106

Rajkowska, J. (2007a). Dotleniacz. Plac Grzybowski w Warszawie [wideo]. Pobrano z http://www.artmuseum. $\mathrm{pl} /$ filmoteka/?l=0\&id=1380

Rajkowska, J. (2007b). Dotleniacz. Tymczasowa instalacja artystyczna w przestrzeni publicznej Warszawy. Centrum Sztuki Wspótczesnej. Pobrano z http://csw.art.pl/index.php?action=wydarzenie\&id=196

Rajkowska, J. (2009). Rajkowska. Przewodnik Krytyki Politycznej. Warszawa: Wydawnictwo Krytyki Politycznej.

Rajkowska, J. (2010). Rzeczywistość milionpostaciowa. Joanna Rajkowska w rozmowie z Magdą Raczyńską. Obieg (Dotleniacz / Oxygenator), (1-2 (81-82)), 70-81. 
Ringelblum, E. (1983). Kronika getta warszawskiego. Warszawa: Czytelnik.

Schlör, J. (2003). From Remnants to Realities: Is There Something Beyond a „Jewish Disneyland” in Eastern Europe? Journal of Modern Jewish Studies, 2(2), 148-158. doi:10.1080/1472588032000101620

Smith, M. M. (2012). Transcending, Othering, Detecting: Smell, Premodernity, Modernity. Postmedieval: a Journal of Medieval Cultural Studies, 3, 380-390.

Stammers, A. H., \& Throwbridge, C. C. (2008). Principles of Oxygenator Function: Gas exchange, Heat Transfer, and Operation. W G. Gravlee (Red.), Cardiopulmonary Bypass: Principles And Practice (ss. 47-62). Philadelphia: Lippincott Williams and Wilkins.

Szczęsny, J. (b.d.). Miniaturowe znaczy możliwe. Dom Kereta. Pobrano z http://domkereta.pl/filter/ architektura/Miniaturowe-znaczy-mozliwe-Architekt-Jakub-Szczesny-o-projekcie

Thorsheim, P. (2006). Inventing Pollution: Coal, Smoke, and Culture in Britain Since 1800. Athens: Ohio University Press.

Tokarska-Bakir, J. (2008). Legendy o krwi. Antropologia przesądu. Warszawa: W.A.B.

Trebińska, E., \& Barańska, K. (2008). Roczna ocena jakości powietrza w województwie mazowieckim. Raport za rok 2007. Warszawa: Wojewódzki Inspektorat Ochrony Środowiska.

Waligórska, M. (2008). Reflektorem w zapomniane: odkrywanie małych Jerozolim. W M. Murzyn-Kurpisz \& J. Purchla (Red.), Przywracanie pamięci. Rewitalizacja zabytkowych dzielnic żydowskich w miastach Europy Środkowej (ss. 99-116). Kraków: MCK.

Warsza, J. (2010). Utleniacz. Obieg (Dotleniacz / Oxygenator), (1-2 (81-82)), 168-171.

Wilczyk, W. (2009). Niewinne oko nie istnieje. Łódź, Kraków: Atlas Sztuki, Korporacja Ha!art.

Zaborowska, M. J. (2004). Reading Transparent “Constructions of History”; or, Three Passages through (in) Visible Warsaw. W S. Forester, M. J. Zaborowska, \& E. Gapova (Red.), Over the Wall / After the Fall: Post-Communist Cultures through a East-West Gaze (ss. 97-119). Bloomington: Indiana University Press.

Zafran, E. (1979). Saturn and the Jews. Journal of the Warburg and Courtauld Institutes, 42, 16-27. doi:10.2307/751082

Zawadzki, J. (1997). Kościót Wszystkich Świętych w Warszawie. Warszawa: Parafia Wszystkich Świętych.

Zielińska, M. (1995). Warszawa - dziwne miasto. Warszawa: Instytut Badań Literackich PAN.

\section{The Post-Jewish Space}

Abstract: The paper offers a critical analysis of a prevalently used contemporary Polish design strategy of alteration and modification, practiced on the former Jewish districts in Poland. A majority of these districts' urban substance consists of property once belonging to Polish Jews, and appropriated by non-Jewish Poles during the Holocaust and after 1945. Such property and its urban space are described in Polish language as a 'post-Jewish' ones (mienie pożydowskie).

The article analyses two parallel cultural processes of contemporary adaptation of this urban space. First of these processes is focused on the concept of Jewish Space, a social idea proposed in 1999 by Diana Pinto. The Jewish Space, envisaged as a cultural and material space of an encounter between European Jews and non-Jews, in its Polish interpretation becomes free from any requirement of a Jewish presence. A social practice resulting from such interpretation differs radically from Pinto's original idea.

The second reviewed process concerns the physical construction of thus defined 'space of encounter'. Its practice is analysed on an example of Oxygenator, an urban intervention by Joanna Rajkowska, installed in Warsaw in 2007. This work, one of first Polish attempts to create a physical space of encounter, despite of its altruistic principles could not fully go beyond the boundaries of the Polish discourse on the exclusivist 'dialogue'. Consequently, a cultural vocabulary it allowed remains limited to meanings more likely to result with exclusion than with a possibility of participation.

Keywords: Warsaw, Polish-Jewish relations, Jewish property, place and space, public art 